http://jmscr.igmpublication.org/home/ ISSN (e)-2347-176x ISSN (p) 2455-0450 crossref DOI: https://dx.doi.org/10.18535/jmscr/v7i8.107

Journal Of Medical Science And Clinical Research

\title{
Biacromial Breadth: A Tool to Measure Stature
}

\author{
Authors \\ Dr Parul ${ }^{1}$, Dr Monica Jain ${ }^{2}$, Dr Lovesh Shukla ${ }^{3}$, Dr Dalbir Kaur ${ }^{4}$ \\ ${ }^{1}$ MD Anatomy, Demonstrator, Department of Anatomy, MAMC AGROHA, Hisar, Haryana \\ ${ }^{2}$ MD Anatomy, Professor, Department of Anatomy, MAMC AGROHA, Hisar, Haryana \\ ${ }^{3}$ MS Anatomy, Senior Professor and Head of Department, Department of Anatomy, MAMC AGROHA, \\ Hisar, Haryana \\ ${ }^{4}$ MD Anatomy, Associate Professor, Department of Anatomy, MAMC AGROHA, Hisar, Haryana
}

\begin{abstract}
Background: Stature is one of the biological characteristics often used in forensic anthropology.

Aim: To determine the relationship of stature with bi-acromial breadth in North India and to derive regression equations for estimation of stature in males and females.

Material and Methods: The present study was conducted on 150 male and 150 female, in the age group of 20-40 years. Anthropometer rod was used for measurement of stature of the subject. Bi-acromial breadth was measured with the help of spreading calliper.

Results: Linear regression analysis was performed and regression equations for predicting stature from biacromial breadth were derived. Correlation coeffcient for predicting stature from bi-acromial breadth were 0.49 and 0.31 in males and females respectively.

Conclusion: This study provides an additional tool of stature estimation particularly in absence of other measures.

Keywords: Stature, Bi-acromial Breadth, Anthropometer Rod, Spreading Calliper.
\end{abstract}

\section{Introduction}

Stature is one of the most used anthropometric dimension. Stature estimation from various measurements like foot length and breadth, hand length and breadth and length of long bones have been extensively studied in different populations by various authors. ${ }^{[1-4]}$ The literature available for stature estimation from bi-acromial breadth (BAB) is scanty. ${ }^{[5-9]}$ The upper part of dorsal surface of scapula has a large bony projection called spinous process or spine of scapula. Acromion process is the continuation of lateral end of spine of scapula. ${ }^{[10]} \mathrm{Bi}$-acromial breadth is the distance between "acromiale point" on each scapula, which is the most lateral point on the acromion process. This length was measured in subjects in an erect posture and arms hanging down by the sides of the body. ${ }^{[1]}$ The present study was undertaken to estimate the correlation between stature of an individual and $\mathrm{BAB}$, both in males and females.

\section{Material and Methods}

The present study was conducted after permission from Institutional Ethical Committee on 300 subjects (150 male and 150 female) between 2040 years of age. Subjects were the willing attendant of patients attending the outpatient department of the hospital of Maharaja Agrasen Medical College, Agroha, Hisar (Haryana). 
Individual with apparent physical deformity, growth and developmental defects were excluded from the study. The aims and objectives of study and procedures were explained to subjects in their own language and a written consent was obtained from them in pre-approved and predesigned format. Stature was measured using anthropometer rod (minimum count $0.5 \mathrm{~mm}$ ) while $\mathrm{BAB}$ was measured using round tipped spreading caliper (minimum count $0.5 \mathrm{~mm}$ ). Data was recorded on computer and analyzed statistically using SPSS software (version 20.0).

\section{Measurements}

- Stature was measured by making the subject to stand bare footed on a horizontal platform in erect posture, keeping the head in Frankfort horizontal plane. It was measured as a vertical distance from the vertex of the subject to the floor on which subject is standing. Movable horizontal piece of anthropometer rod was brought in contact with the vertex in midsagittal plane and stature was recorded ${ }^{\text {[11] }}$

- $\mathrm{BAB}$ was measured by making the subject to stand erect with arms hanging down on the sides of body. By standing behind the subject, acromiale of both sides were felt and marked with the help of skin marking pencil. It was measured by placing the round tipped spreading caliper on marked points.

\section{Observations and Results}

Table 1: Showing range, Mean, SD, SE of stature and BAB in male and female

\begin{tabular}{|l|c|c|c|c|c|c|c|c|}
\hline \multirow{2}{*}{ Sex } & \multicolumn{4}{|c|}{ Stature (mm) } & \multicolumn{3}{c|}{ BAB(mm) } \\
\cline { 2 - 9 } & Range & Mean & SD & SE & Range & Mean & SD & SE \\
\hline Male and female combined & $1400-1800$ & 1598.53 & 95.76 & 5.52 & $220-394$ & 308.26 & 28.45 & 1.642 \\
\hline Male & $1480-1840$ & 1668.00 & 67.83 & 5.53 & $250-394$ & 320.98 & 24.11 & 5.538 \\
\hline Female & $1400-1720$ & 1529.07 & 63.91 & 5.21 & $220-352$ & 295.53 & 26.77 & 1.969 \\
\hline
\end{tabular}

To estimate stature from $\mathrm{BAB}$, regression equations were derived separately for male and $\mathrm{Y}=\mathrm{x} \times \mathrm{b}+\mathrm{c}(\mathrm{Y}=$ stature, $\mathrm{x}=\mathrm{BAB}, \mathrm{b}=$ regression female separately as well as together. [Table 2]

coefficient, $\mathrm{c}=$ constant)

Table 2 Showing Regression equations, correlation coefficient and 95\% confidence interval for stature estimation from $\mathrm{BAB}$ in male and female

\begin{tabular}{|l|c|c|c|}
\hline & Regression equations & $\begin{array}{c}\text { Correlation } \\
\text { coefficient r }\end{array}$ & $\begin{array}{c}\text { 95\% confidence } \\
\text { interval }\end{array}$ \\
\hline Male \& Female combined & Stature $=\mathrm{BAB} \times 1.920+1006.54$ & 0.571 & $1.605-2.236$ \\
\hline Male & Stature $=\mathrm{BAB} \times 1.389+1223.744$ & 0.492 & $0.986-1.782$ \\
\hline Female & Stature $=\mathrm{BAB} \times 0.746+1308.484$ & 0.313 & $0.378-1.1150$ \\
\hline
\end{tabular}

Statistically significant correlation was observed between stature and $\mathrm{BAB}$ in both sexes. Correlation between stature and $\mathrm{BAB}$ in males and females were 0.49 and 0.31 respectively. In males and females together it was 0.57. (Scatter plot 1,2 and 3)

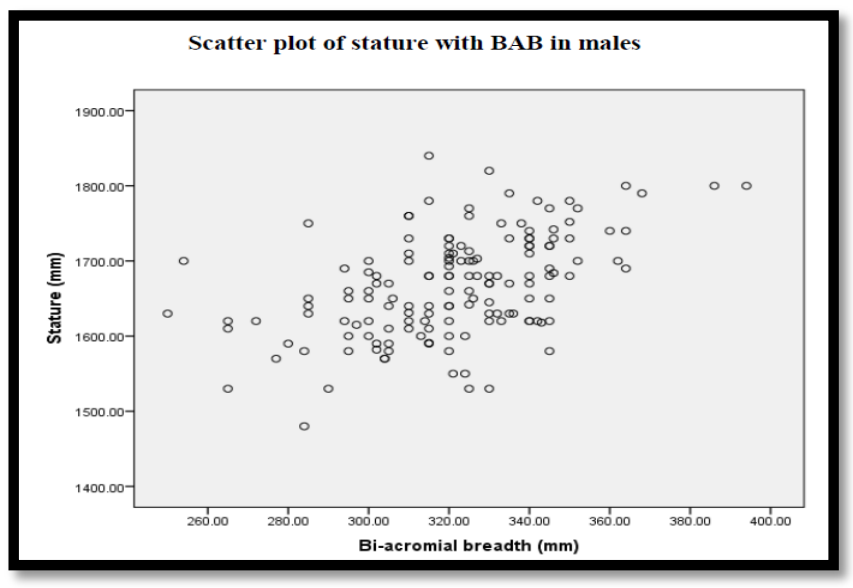

Scatter plot 1 showing correlation of stature with $\mathrm{BAB}$ in males. 


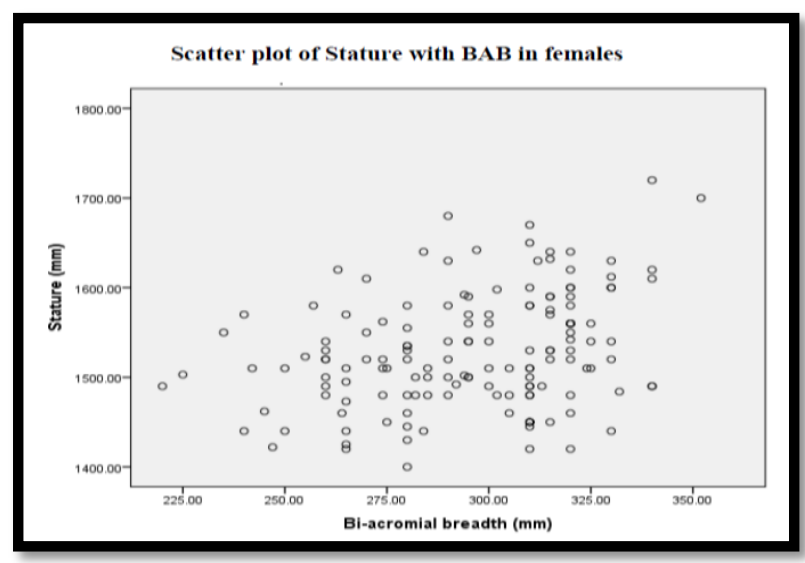

Scatter plot 2 showing correlation of stature with $\mathrm{BAB}$ in females.

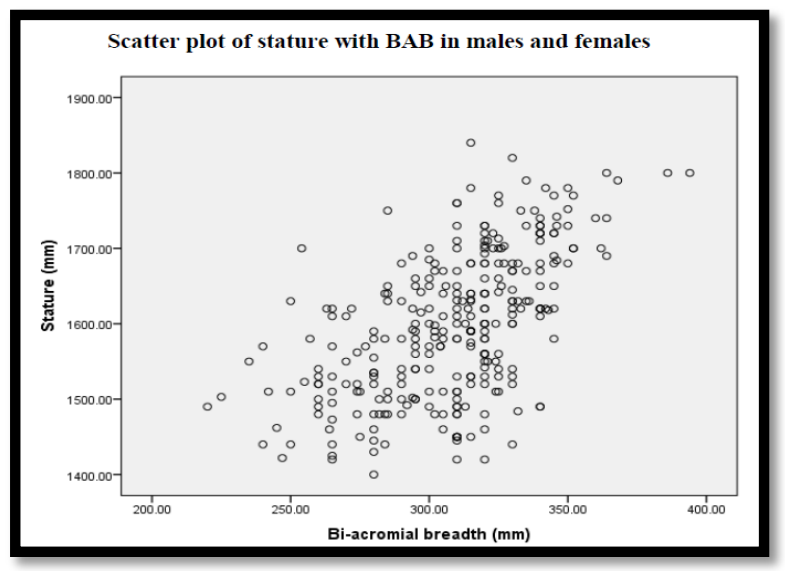

\section{Discussion}

$\mathrm{BAB}$ is not so frequently used tool to estimate stature. In various studies, BAB is more in males as compared to females irrespective of race, geographical area and socioeconomic status as in present study. ${ }^{[5-9]}$ Males in comparison to females, tend to develop broader shoulder from onset of puberty as shoulder growth spurt is more marked in them. This may be due to fact that cartilage cells in shoulder region are specialized to respond to male sex hormone testosterone. ${ }^{[12]}$

A wide range of $\mathrm{BAB}$ is being measured ranging from $284.5-445 \mathrm{~mm}$ and $230.3-403 \mathrm{~mm}$ in male and female population respectively by different workers [table 3]. These findings of present study are close to the findings of Koulapur and Mestri. Genetic drift may be responsible for this type of diversity of physical anthropological variation between different populations. ${ }^{[13]}$

Scatter plot 3 showing correlation of stature with $\mathrm{BAB}$ in both males \& females.

Table 3 Showing Comparison of range and mean of BAB in different studies

\begin{tabular}{|c|c|c|c|c|c|c|}
\hline Name of Researchers & $\begin{array}{r}\text { Geographical area } \\
\text { of study group }\end{array}$ & $\begin{array}{r}\text { Age group } \\
\text { (years) }\end{array}$ & Sex & $\begin{array}{c}\text { Range c } \\
\text { Min }\end{array}$ & $\begin{array}{l}\text { Max } \\
\text { Max }\end{array}$ & $\begin{array}{c}\text { Mean of } \\
\text { BAB }(\mathrm{mm})\end{array}$ \\
\hline \multirow{2}{*}{ Momonchand \& Devi } & \multirow{2}{*}{ Imphal, India } & \multirow{2}{*}{$21-86$} & M & 350 & 510 & 445.0 \\
\hline & & & $\mathrm{F}$ & 320 & 480 & 403.0 \\
\hline \multirow{2}{*}{ Koulapur \& Mestri } & \multirow{2}{*}{ Karnataka, India } & \multirow{2}{*}{ Around 23} & $\mathrm{M}$ & 302 & 402 & 342.0 \\
\hline & & & $\mathrm{F}$ & 256 & 330 & 299.0 \\
\hline \multirow[t]{2}{*}{ Patel et al } & \multirow{2}{*}{ Gujarat, India } & \multirow{2}{*}{$22-44$} & $\mathrm{M}$ & 350 & 489 & 412.0 \\
\hline & & & $\mathrm{F}$ & 300 & 460 & 370.0 \\
\hline \multirow{2}{*}{ Mishra et al } & \multirow{2}{*}{$\begin{array}{l}\text { Madhya Pardesh, } \\
\text { India }\end{array}$} & \multirow{2}{*}{$22-27$} & $\mathrm{M}$ & 262 & 377 & 319.4 \\
\hline & & & $\mathrm{F}$ & 262 & 339 & 294.7 \\
\hline \multirow{2}{*}{ Ozaslan et al } & \multirow{2}{*}{ Turkey } & $20-52$ & $\mathrm{M}$ & 273 & 458 & 386.0 \\
\hline & & $20-49$ & $\mathrm{~F}$ & 273 & 412 & 349.0 \\
\hline
\end{tabular}

Apart from India, studies have been conducted on other populations like on Turkish one by Ozaslan et al and on Sri Lankan population by Balasuriya. ${ }^{[14]}$ Mean BAB of both males and females of present study are lesser than that of Turkish and Sri Lankan populations. Turksih are tall statured and well built ${ }^{[15]}$ similarly Sri Lankan population is Dravidians which is better built as compared to Indo-Aryans population of present study.
Correlation coefficient of regression equations for estimation of stature from $\mathrm{BAB}$ in males is less as compared to the study of Shah et al (0.56), while it is comparable with the study of Koulapur and Mestri. (0.50). Whereas in females, correlation coefficient is less as compared to the study of Momonchand and Devi (0.45), Koulapur et al (0.60) and comparable with the study of Mishra et al (0.32). 
Various researchers have found significant correlation between height and different parts of body. Jadhav and shah derived regression equations between head length and height in Gujarat region and correlation coefficient between height and head length came out to be 0.53 which is significant. ${ }^{[16]}$ In a study done by Patel et al for estimation of stature from hand length, positive correlation was found to be significant $(r=0.51$ in males and $\mathrm{r}=0.50$ in females. ${ }^{[17]}$ The highest correlation coefficient was observed in the study done using foot length as a tool for stature estimation by Charnalia et al $(r=0.95){ }^{[18]}$ while in females it was observed by Supare et al $(r=0.90)$ using arm span ${ }^{[19]}$ as a tool for stature estimation. The correlation coefficient with clavicle in a study done by Jit and Singh came out to be 0.56 in males and 0.68 in females. ${ }^{[20]}$

\section{Conclusion}

There exists a significant correlation of stature with bi-acromial breadth of an individual in both the sexes. Stature can be estimated with biacromial breadth even when only upper parts of trunk are is available. The present study explores the usability of dimensions of upper trunk as predictor of stature in population of Haryana. These data can be very useful for anthropologists and medicolegal experts in identification of individuals as many times (in bomb blast/ rail accident/ airplane crashes, murders) only trunk of individual is available for identification.

\section{Limitations}

Our main limitation was small sample size and we had covering a small part of India (Northern Region)

\section{Acknowledgment}

I want to thank Mr. Suryamani Pandey, Assitant Professor, Department of Community Medicine for his statistical help.

\section{Conflicts of Interests: None}

\section{References}

1. Krishan K. Estimation of stature from footprint and foot outline dimensions in gujjars of North India. Forensic Sci Int 2008;175 (2-3):93-101.

2. Jasuja OP, Singh G. Estimation of stature from hand and phalange length. J Indian Acad Forensic Med 2004;26 (3):100-6.

3. Ilayperuma I, Nanayakkara G, Palahepitiya N. A model for the estimation of personal stature from the length of forearm. Int J Morphol 2010;28 (4):10816.

4. Chikhalkar BG, Mangaonkar AA, Nanandkar SD, et al. Estimation of stature from measurements of long bones, hand and foot dimensions. $\mathbf{J}$ Indian Acad Forensic Med

5. Momonchand A, Devi T. Determination of Stature from the inter-acromial length. Journal of Forensic Medicine and Toxicology. 1999; 16(1):72-73.

6. Koulapur VV, Agarwal SS, Mestri SC. Estimation of Stature by Anthropometric Measurements of Inter-Acromial Length. J Indian Acad Forensic Med. 2009; 32(2):329-31.

7. Patel SH, Bastiya BK, Kumar L, Kumaran S. Estimation of adult human stature from measurements of inter-acromial length in Gujarati population of India. J Indian Acad Forensic Med. 2015; 37:365-68.

8. Mishra M, Tiwari A, Naik DC. Determination of individual's height by postcranial measurements in Rewa region of Madhya Pradesh. Int J Med Sci Public Health. 2014; 3(10):1279-82.

9. Ozaslan A, Karadayi B, Kolusayin MO, et al. Stature estimation from bi-acromial and bi-iliocristal measurements. Rom J Leg Med 2011;19 (3):171-6.

10. Stranding S. Gray's Anatomy- The anatomical basis of clinical practice. Edinburgh: Churchill Livingstone; 2008;40 th ed: $\mathrm{p} 1355$. 
11. Singh SP, Mehta P. Human body measurements: concepts and application. New Delhi: PHI learning Private Limited 2009.

12. Tanner JM, Tanner J. Foetus into Man:Physical growth from conception to maturity. Harvard University Press. p.68.

13. Sarma R, Sarma S, Baruah T. Somatometric study of Mongoloid community- "The Plain-Tiwas" of central Asaam. Int J Pure App Biosci. 2014; 2(2):142-48.

14. Balasuriya P. Anthropometric study of medical students. Ceylon J med Sci. 1988; 31:19-24

15. Goutam. Anthropological definitions and classifications of the population in India. available from: http://www.shareyouressays.com/104609/a nthropological-definitions-andclassifications-of-population-inindiaexplained accessed on 08 july 2019.

16. Jadav HR, Shah GV. Determination of personal height from the length of head in Gujarat region. J Anat Soc India. 2004; 53(1):20-21.

17. Patel JP, Patel BG. Estimation of stature from hand length in Gujarat region. NHL J Med Sciences. 2014; 3(1):41-4.

18. Charnalia VM. Anthroplogical study of foot and its relationship to stature in different castes and tribes of Pondicherry state. J Anat Soc of India 1961;10: 26-30.

19. Suapre MS, Bagul AS, Pandit SV, et al. Estimation of stature from arm span in medical students of Maharashtra, India. Annals of Medical \& Health Sciences Research 2015; 5 (3):218-21.

20. Jit I, Singh S. Estimation of stature from clavicles. Indian J Med Res 1956; 44 (1):137-55. 